\title{
ANALISIS NILAI MASSAL TANAH TERHADAP NILAI INDIVIDUAL PADA PROPERTI JENIS RUMAH TINGGAL DAN RUKO (Studi Kasus: Kecamatan Gresik, Kabupaten Gresik)
}

\author{
Udiana Wahyu Deviantari*1, Yanto Budisusanto ${ }^{1}$, Haryo Wicaksono슬 ${ }^{1}$ Andy Dediyono ${ }^{2}$ \\ ${ }^{1}$ Departemen Teknik Geomatika, FTSLK-ITS, Kampus ITS Sukolilo, Surabaya, 60111, Indonesia \\ ${ }^{2}$ Masyarakat Profesi Penilai Indonesia \\ e-mail: ${ }^{* 1}$ dianada87@gmail.com
}

\begin{abstract}
Abstrak
Gresik merupakan salah satu kabupaten yang mengalami perkembangan sangat pesat dan menjadi salah satu kota dengan pertumbuhan ekonomi yang tinggi di Indonesia. Akibat dari semakin padatnya kabupaten Gresik maka nilai individual properti di kabupaten Gresik mengalami peningkatan. Tujuan dari penelitian ini adalah untuk membuat peta selisih nilai individual terhadap nilai massal. Memberikan referensi selisih nilai tanah pada properti rumah tinggal dan ruko untuk kemudian dapat dianalisa penyebab adanya selisih nilai individual tersebut.

Peta selisih nilai individual terhadap nilai massal dihasilkan dari overlay zona nilai tanah, Informasi harga properti sampel dan koordinat dari properti sampel. Informasi harga properti sampel yang ada kemudian dihitung menggunakan peraturan penilaian yang dimuat dalam Standar Penilaian Indonesia Edisi Ke 6 tahun 2015 yang kemudian dihitung selisihnya terhadap Nilai Jual Objek Pajak (NJOP).

Selisih nilai massal terhadap nilai individual pada properti jenis ruko memiliki nilai selisih tertinggi pada RUK14 dengan selisih sebesar Rp 17.642.000/m². Nilai selisih terendah pada RUK194 dengan selisih sebesar Rp 142.541/m². Pada properti jenis rumah tinggal, selisih nilai massal terhadap nilai individual memiliki nilai selisih tertinggi pada RU163 dengan selisih sebesar $12.050 .555 / \mathrm{m}^{2}$. Nilai selisih terendah pada RU122 dengan selisih sebesar Rp 75.752/m².
\end{abstract}

Kata kunci : Rumah Tinggal, Ruko, Nilai Individual, Nilai Jual Objek Pajak

\begin{abstract}
Gresik is one of the sub-districts that experienced rapid growth and become one of the cities with high economic growth in Indonesia. As a result of the denser Gresik regency, the value of individual property in Gresik regency has increased. The purpose of this study is to make a map of individual value differences against mass values.

Map of individual value differences to bulk values generated from overlay of land value zone, Information on sample property prices and coordinates of sample properties. The price information of the existing sample properties is then calculated using the assessment rules contained in the Indonesian Assessment Standards 6th Edition 2015 which then calculated the difference to the Value of Object of Tax (NJOP).

The difference in the shop type property has the highest difference value in RUK14 with the difference of Rp $17,642,000 / \mathrm{m}^{2}$. The lowest difference value in RUK194 with difference of $R p 142,541 / \mathrm{m}^{2}$. In residential type properties, the difference in bulk value to individual values has the highest difference value on RU163 with a difference of 12,050,55 $/ m^{2}$. The lowest difference value in RU122 with difference of $R p 75.752 / \mathrm{m}^{2}$.
\end{abstract}

Keywords : Housing, Shophouse, Individual Value, Tax Object Selling Value (NJOP)

\section{PENDAHULUAN}

Gresik merupakan kabupaten/kota kedua di Jawa Timur yang memiliki pertumbuhan penduduk cukup signitifkan sejak tahun 2000 dengan pertumbuhan penduduk per tahunnya mencapai angka 1,59\%. Hal ini dibuktikan dengan pertambahan jumlah penduduk dari tahun 2006 hingga tahun 2011 saja mengalami pertambahan hingga 50 ribu penduduk (Kamarzuki, 2013). Pada tahun 2017, Gresik sudah direncanakan untuk memiliki hotel dan mall baru yang akan selesai pada tahun 2019 (Arfah, 2017). Akibat dari semakin padatnya kabupaten Gresik maka nilai tanah properti di kabupaten Gresik mengalami peningkatan. Akibat dari semakin padatnya 
kabupaten Gresik maka nilai tanah properti di kabupaten Gresik mengalami peningkatan.

Peningkatan nilai tanah properti terjadi dikarenakan adanya faktor permintaan yang cukup tinggi dari masyarakat. Peningkatan tersebut umumnya terlihat dari harga sejumlah properti yang mengalami kenaikan. Kenaikan tersebut menyebabkan nilai tanah per meter persegi tidak lagi sesuai dengan nilai massal yang ada. Hal ini menyebabkan adanya perbedaan dengan nilai individual dari properti itu sendiri yang berujung pada harga jual properti tersebut menjadi tinggi.

Properti yang umum mengalami peningkatan nilai individual adalah rumah tinggal, perumahan, ruko dan perkantoran (Arfah, 2017). Rumah tinggal dan ruko merupakan properti yang paling sering terjadi transaksi karena dua properti tersebut merupakan properti utama dalam roda perekonomian di kabupaten Gresik.

Pada penelitian ini akan membandingkan nilai massal terhadap nilai individual pada properti jenis rumah tinggal dan ruko. Data yang digunakan dalam penelitian ini yaitu data pasar yang diambil langsung dari lapangan. Data pasar tersebut diolah untuk dihitung nilai individualnya dengan metode perhitungan yang sesuai dengan Standar Penilaian Indonesia Edisi ke 6 tahun 2015. Hasil perhitungan digunakan untuk mencari selisih antara nilai individual properti tersebut dengan nilai massal. Hasil perhitungan tersebut kemudian dianalisa secara spasial dan dibuat peta tematiknya sebagai hasil akhir dari penelitian ini.

\section{METODE}

Metode pengolahan data pada penelitian ini adalah sebagai berikut :

a. Data yang digunakan yaitu data koordinat lokasi properti dan data harga properti. Data koordinat lokasi properti diambil dengan menggunakan GPS handheld dan data harga properti didapatkan dengan langsung mendata properti yang dijual dan dituliskan dalam form survei.

b. Koordinat dari properti yang dijadikan sampel di overlay dengan peta Zona Nilai Tanah untuk menghasilkan peta properti.

c. Informasi harga properti yang ada kemudian dihitung dengan prinsip penilaian yang diatur dalam Standar Penilaian Indonesia Edisi ke 6 tahun 2015. d. Menseleksi nilai tanah yang memiliki perbedaan terlalu tinggi atau terlalu rendah. Nilai tanah yang sudah sesuai akan dimasukkan kedalam data attribut di peta sebaran nilai tanah.

e. Melalui koodinat di peta sebaran properti akan diketahui Nilai Jual Objek Pajak tiap zona dilokasi properti tersebut berdiri. Dari Nilai Jual Objek Pajak tersebut akan dicari selisihnya terhadap nilai tanah individualnya. Setelah dihitung maka akan didapatkan selisihnya dan hasilnya akan digambarkan dalam sebuah peta tematik. Setelah itu hasilnya akan dianalisa secara spasial untuk dicari faktor yang mempengaruhi perbedaan nilai tersebut.

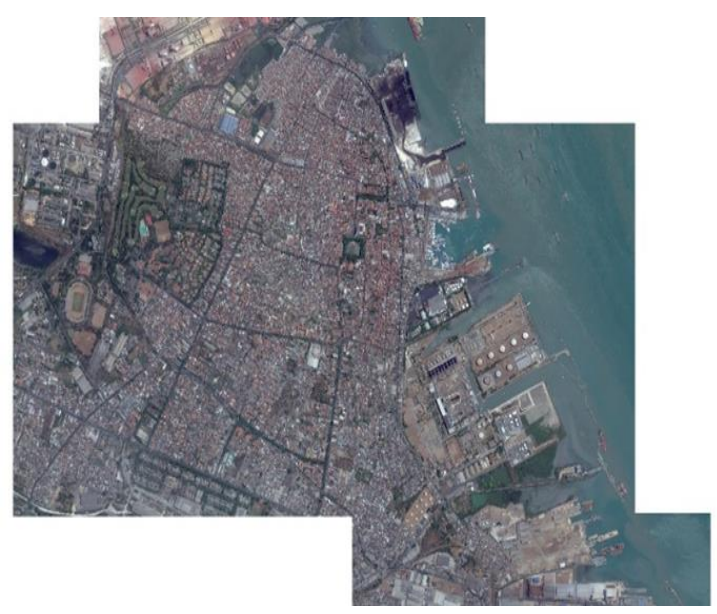

Gambar 1. Citra Kecamatan Gresik (SAS Planet, 2016)

\section{HASIL DAN PEMBAHASAN}

Data informasi harga properti yang didapatkan dari survei lapangan memerlukan proses penyesuaian untuk mendapatkan nilai tanah yang sesungguhnya. Penyesuaian yang dilakukan menggunakan standar yang sudah diatur dalam Standar Penilaian Indonesia Edisi ke 6 tahun 2015. Berikut Penjelasan penyesuaian yang telah dilakukan antara lain:

1. Penyesuaian sumber data, Pada tahap ini datadata informasi harga tanah disesuaikan dari sektor pemberi informasi (pemilik, warga, agen, makelar dan lain-lain. Untuk informasi yang didapatkan dari pemilik diberi prosentase $0 \%$, untuk agen dan makelar diberikan prosentase ()10\% hingga (-)20\% karena adanya keuntungan yang diambil oleh pihak marketing dan keuntungan perusahaan maupun keuntungan sesama makelar atau broker. Untuk informasi dari warga diberikan prosentas (-)5\%. 
2. Penyesuaian luas bidang, setiap lahan tanah biasanya akan berbeda dari segi luasnya, jika suatu lahan dalam satu zona ditawarkan dengan luas lebih besar akan memiliki harga yang lebih murah dibandingkan dengan lahan yang luasnya kecil. Oleh karena itu diberikan prosentase yang disesuaikan dengan luas dan harga dari lahan tanah yang ada.

3. Penyesuaian kedudukan tanah dilakukan dengan menambah atau mengurangi prosentase antara data acuan dan data pembanding. Kedudukan tanah dipengaruhi dari letak keberadaan dari bidang tersebut. Pada penelitian ini untuk lahan yang terletak di pinggir jalan akan diberikan prosentase $0 \%$, tengah jalan $+/-5 \%$, dalam jalan $+/-10 \%$.

4. Penyesuaian waktu, pada tahap ini data-data informasi harga tanah akan disesuaikan menurut waktu transaksi dari informasi harga properti. Penyesuaiannya dilakukan dengan memberikan prosentase $1 \%$ untuk tiap bulan yang sudah terlewati semenjak terjadinya transaksi hingga pengambilan data.

5. Penyesuaian lokasi, pada penyesuaian lokasi, dilakukan penyesuaian berdasarkan aksesibilitas, lokasi dan hal-hal lain yang tidak disesuaikan dalam jenis parameter yang lain. Nilai prosentase penyesuaian juga bervariasi didasarkan pada perbedaan parameter acuan dan pembanding untuk menyesuaikan.

Beberapa hasil dari perhitungan nilai tanah tersebut dapat dilihat pada tabel 1 dan tabel 2 .

Tabel 1. Hasil Perhitungan Nilai Tanah Pada Jenis

\begin{tabular}{ccc}
\multicolumn{3}{c}{ Properti Ruko } \\
\hline No & Kode Data & $\begin{array}{c}\text { Indikasi Nilai Pasar Tanah } \\
(\text { Rp/m2) }\end{array}$ \\
\hline 1 & & $24,586,957$ \\
2 & RUK191 & $2,864,286$ \\
3 & RUK4 & $19,215,000$ \\
4 & RUK7 & $13,440,000$ \\
5 & RUK195 & $18,401,333$ \\
6 & RUK1 & $13,620,020$ \\
7 & RUK15 & $13,817,769$ \\
\hline
\end{tabular}

Tabel 2. Hasil Perhitungan Nilai Tanah Pada Jenis Properti Rumah Tinggal

\begin{tabular}{ccc}
\hline No & Kode Data & $\begin{array}{c}\text { Indikasi Nilai Pasar Tanah } \\
\text { (Rp/m2) }\end{array}$ \\
\hline 1 & RU21 & $1,733,900$ \\
2 & RU27 & $4,063,000$ \\
3 & RU29 & $1,236,111$ \\
4 & RU8 & $12,409,457$
\end{tabular}

\begin{tabular}{ccc}
5 & RU130 & $19,127,250$ \\
6 & RU200 & $9,090,969$ \\
7 & RU71 & $6,322,750$ \\
8 & RU17 & $3,295,600$ \\
9 & RU76 & $3,110,625$ \\
10 & RU77 & $3,401,250$ \\
\hline
\end{tabular}

Berdasarkan contoh perhitungan pada tabel 1 dan 2, dapat terlihat tertinggi adalah RUK191 dengan indikasi nilai pasar tanah adalah $\mathrm{Rp} 24.586 .957 / \mathrm{m}^{2}$. Hal ini terjadi karena RUK191 terletak pada lokasi yang bersifat komersil dan dilewati oleh jalan arteri menuju kecamatan Kebomas yang merupakan kecamatan yang memiliki perkembangan pesat dan merupakan kecamatan dimana Kota Gresik Baru berada. Untuk indikasi nilai pasar tanah terendah terjadi pada RUK4 dengan nilai Rp $2.864 .286 / \mathrm{m}^{2}$. Hal ini terjadi karena RUK4 berada lokasi yang cukup jauh dari jalan arteri provinsi serta dekat dengan pelabuhan milik pertamina dan Pembangkit Listrik Tenaga Gas dan Uap Gresik. Demografi wilayah tersebut berupa permukiman warga.

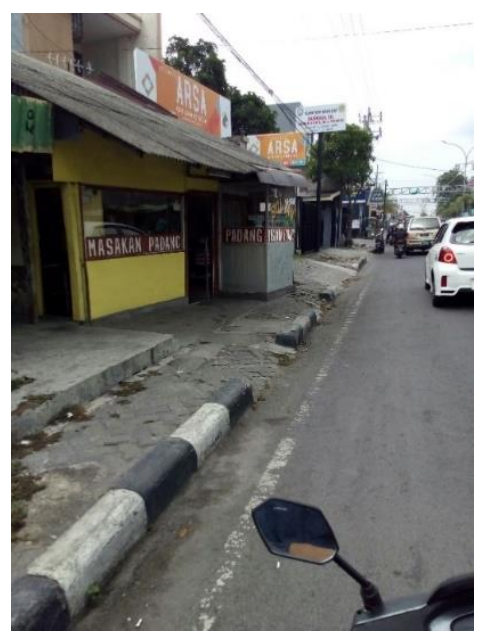

Gambar 2. Kondisi Lapangan Disekitar RUK191

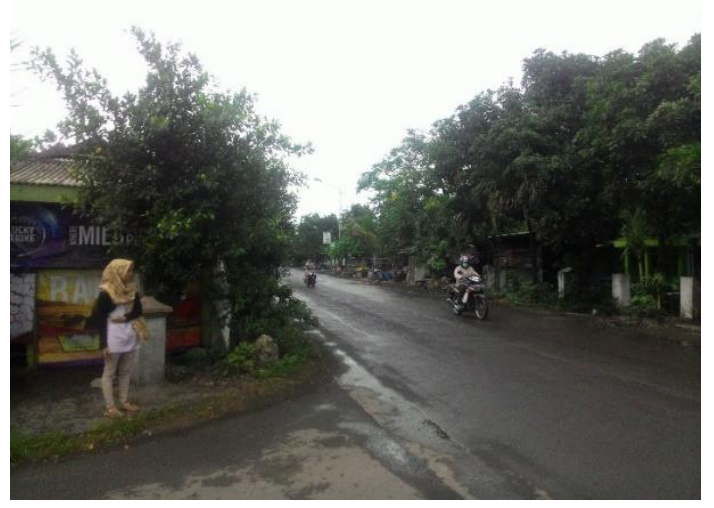

Gambar 3. Kondisi Lapangan Disekitar RUK4 
Pada properti jenis rumah tinggal, RU130 memiliki indikasi nilai pasar tanah tertinggi dengan nilai Rp 19.127.250/m². Hal ini terjadi dikarenakan RU130 berada pada jalan Panglima Sudirman yang berhubungan langsung dengan Jalan Kragran Rembang - Surabaya. Pada wilayah tersebut terdapat banyak Ruko maupun bangunan komersil lainnya. Untuk nilai terendah terdapat pada RU29 dengan indikasi nilai pasar tanah $\mathrm{Rp} 1.236 .111 / \mathrm{m}^{2}$. Hal ini terjadi dikarenakan RU29 terletak pada permukiman berupa jalan dengan lebar $2 \mathrm{~m}$ dan termasuk ke dalam jalan kelas III C.

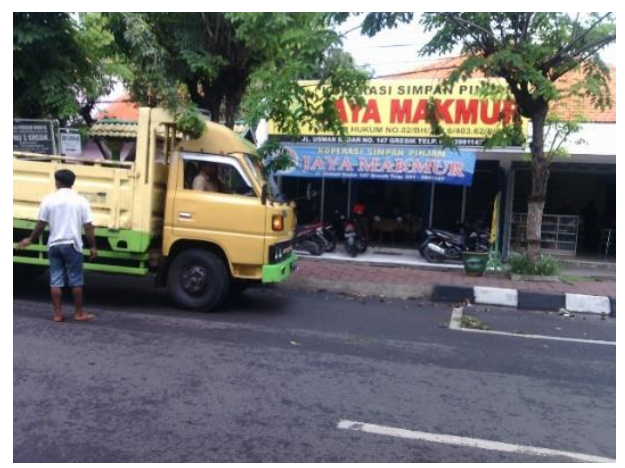

Gambar 4. Kondisi Lapangan Disekitar RU130

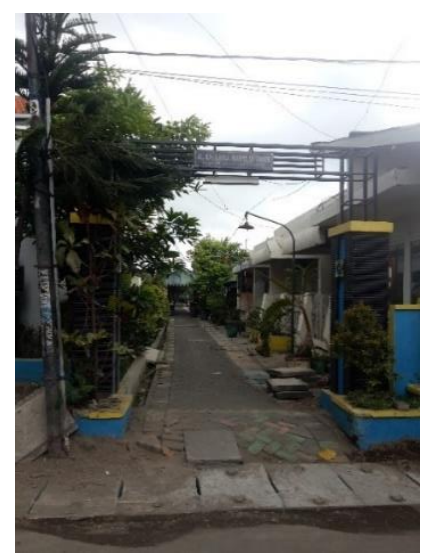

Gambar 5. Kondisi Lapangan Disekitar RU29

Menurut Oloke, Simon dan Adesulu, 2013, bahwa variasi nilai tanah dan properti terjadi karena adanya pengaruh gabungan dari lokasi, demografi penduduk dan tingkat kemajuan ekonomi pada wilayah tempat properti atau tanah tersebut berada.

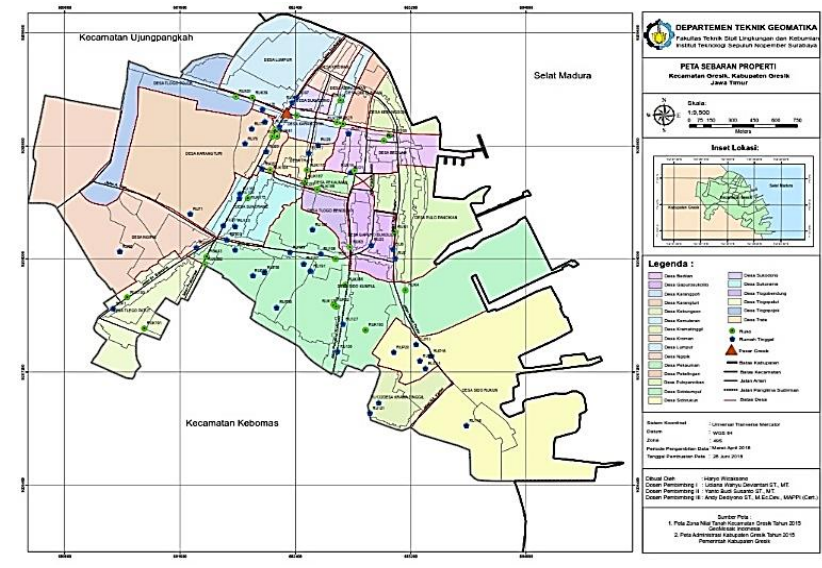

Gambar 6. Peta Sebaran Properti

Proses perhitungan selisih nilai individual terhadap nilai massal didapatkan dengan mengurangi hasil perhitungan nilai tanah dengan Nilai Jual Objek Pajak pada lokasi properti tersebut berdiri. Beberapa hasil perhitungan tersebut dapat dilihat pada tabel 3 dan tabel 4 .

Tabel 3. Hasil Perhitungan Selisih Nilai Pada Jenis Properti Ruko

\begin{tabular}{cccc}
\hline No & Kode Data & $\begin{array}{c}\text { Selisih Nilai } \\
\left(\mathrm{Rp} / \mathrm{m}^{2}\right)\end{array}$ & $\begin{array}{c}\text { Prosentase } \\
\text { Kenaikan } \\
\text { Terhadap } \\
\text { NJOP }\end{array}$ \\
\hline 1 & RUK19 & 14.779 .590 & $181.46 \%$ \\
2 & RUK4 & 2.745 .990 & $1121.55 \%$ \\
3 & RUK7 & 17.642 .000 & $44.33 \%$ \\
4 & RUK195 & 9.695 .000 & $258.88 \%$ \\
5 & RUK1 & 14.246 .333 & $342.87 \%$ \\
6 & RUK15 & 13.620 .020 & $167.22 \%$ \\
7 & RUK18 & 13.817 .769 & $169.65 \%$ \\
\hline
\end{tabular}

Tabel 4. Hasil Perhitungan Selisih Nilai Pada Jenis Properti Rumah Tinggal

\begin{tabular}{cccc}
\hline No & Kode Data & $\begin{array}{c}\text { Selisih Nilai Pasar } \\
\text { Tanah }\left(\mathrm{Rp} / \mathrm{m}^{2}\right)\end{array}$ & $\begin{array}{c}\text { Prosentase } \\
\text { Kenaikan } \\
\text { Terhadap } \\
\text { NJOP }\end{array}$ \\
\hline 1 & RU21 & 160.900 & $10.23 \%$ \\
2 & RU27 & 2.789 .000 & $218.92 \%$ \\
3 & RU22 & 1.890 .667 & $37.11 \%$ \\
4 & RU8 & 8.54 .457 & $198.66 \%$ \\
5 & RU78 & 6.623 .600 & $421.08 \%$ \\
6 & RU200 & 215.969 & $214.10 \%$ \\
\hline
\end{tabular}

Selisih nilai individual terhadap nilai massal pada kedua jenis properti yang ada di kecamatan Gresik bervariasi. Variasi selisih nilai ini terjadi karena adanya pengaruh gabungan dari tingkat kemajuan ekonomi maupun hal lain seperti harga properti disekitar wilayah tempat properti berdiri yang menyebabkan tinggi maupun rendahnya selisih nilai. American Institute of Appraiser pada bukunya 
tahun 2010 menentukan bahwa metode penilaian memasukkan hal-hal yang bersifat ekonomi seperti biaya yang dikeluarkan untuk membuat sebuah properti baru hingga tingkat kapitalisasi ekonomi dalam menentukan nilai properti dan nilai tanah.

Hasil dari selisih nilai yang ada dibagi kedalam 5 kelompok range selisih nilai. Pembagian kelompok range selisih nilai adalah sebagai berikut :
Central Business District yang ada pada kecamatan Gresik adalah pasar Gresik yang berbentuk sebuah wilayah perdagangan dan pada penelitian ini diambil titik tengah jalan yang ada pada pasar Gresik. Untuk jalan yang dijadikan parameter adalah Jalan Panglima Sudirman yang berhubungan langsung dengan Jalan Kragran - Rembang Surabaya yang merupakan jalan arteri antar provinsi.

Analisis dilakukan dengan mengambil titik sampel dalam rentang jarak $0,2 \mathrm{~km},<0,2$ sampai $0,4 \mathrm{~km}, 0,4$ $<$ sampai 0,6 km, 0,6 < sampai $<0,8 \mathrm{~km}$ dan $<0,8$ sampai $1 \mathrm{~km}$ dari Pasar Gresik dan Jalan Panglima Sudirman.

Tabel 6. Hasil Analisis Peta Tematik Selisih Nilai Individual Terhadap Nilai Massal Pada Properti Ruko

\begin{tabular}{|c|c|c|}
\hline \multicolumn{3}{|c|}{ Dengan Pasar Gresik } \\
\hline Jarak Dari Pasar Gresik & $\begin{array}{c}\text { Kelompok } \\
\text { Nilai }\end{array}$ & Kode \\
\hline \multirow[t]{4}{*}{$<0,2 \mathrm{~km}$} & $B$ & RUK40 \\
\hline & B & RUK24 \\
\hline & B & RUK41 \\
\hline & $E$ & RUK18 \\
\hline \multirow[t]{5}{*}{$0,2-0,4 \mathrm{~km}$} & $A$ & RUK51 \\
\hline & B & RUK39 \\
\hline & $\mathrm{D}$ & RUK196 \\
\hline & $E$ & RUK19 \\
\hline & $E$ & RUK15 \\
\hline \multirow[t]{4}{*}{$0,4-0,6 \mathrm{~km}$} & A & RUK187 \\
\hline & B & RUK115 \\
\hline & C & RUK188 \\
\hline & $\mathrm{C}$ & RUK189 \\
\hline \multirow[t]{8}{*}{$0,6-0,8 \mathrm{~km}$} & $A$ & RUK7 \\
\hline & A & RUK194 \\
\hline & A & RUK187 \\
\hline & B & RUK115 \\
\hline & $\mathrm{C}$ & RUK188 \\
\hline & $\mathrm{C}$ & RUK189 \\
\hline & $\mathrm{D}$ & RUK195 \\
\hline & $\mathrm{E}$ & RUK14 \\
\hline $0,8-1 \mathrm{~km}$ & - & - \\
\hline
\end{tabular}

Tabel 7. Hasil Analisis Peta Tematik Selisih Nilai Individual Terhadap Nilai Massal Pada Properti Ruko Dengan Jalan Panglima Sudirman 


\begin{tabular}{ccc}
\hline $\begin{array}{c}\text { Jarak Dari Jalan } \\
\text { Panglima } \\
\text { Sudirman }\end{array}$ & $\begin{array}{c}\text { Kelompok } \\
\text { Nilai }\end{array}$ & Kode \\
\hline$<0,2 \mathrm{~km}$ & $\mathrm{C}$ & RUK52 \\
& C & RUK176 \\
& E & RUK193 \\
$0,2-0,4 \mathrm{~km}$ & B & RUK131 \\
& A & RUK166 \\
$0,4-0,6 \mathrm{~km}$ & B & RUK131 \\
$0,6-0,8 \mathrm{~km}$ & E & RUK1 \\
$0,8-1 \mathrm{~km}$ & A & RUK187 \\
& C & RUK188 \\
& C & RUK189 \\
\hline
\end{tabular}

Pada tabel 6 jarak $<0,2 \mathrm{~km}$, dapat terlihat bahwa kelompok rentang selisih nilai $\mathrm{B}$ menjadi nilai yang berpengaruh. Pada jarak 0,2 - 0,4 km, dapat dapat terlihat bahwa kelompok rentang selisih nilai $\mathrm{E}$ menjadi nilai yang berpengaruh. Pada jarak 0,4 $0,6 \mathrm{~km}$, dapat terlihat bahwa kelompok rentang selisih nilai $\mathrm{C}$ menjadi nilai yang berpengaruh. Pada jarak 0,6 - 0,8 km, dapat terlihat bahwa kelompok rentang selisih nilai $A$ menjadi kelompok rentang selisih nilai yang berpengaruh diikuti oleh kelompok rentang selisih nilai C. Pada jarak 0,8 - $1 \mathrm{~km}$ menuju Pasar Gresik, tidak terdapat sampel pada properti ruko. Berdasarkan kelompok rentang nilai selisih yang berpengaruh pada tiap rentang jarak menuju Pasar Gresik dapat terlihat bahwa kenaikan maupun penurunan kelompok rentang nilai selisih yang berpengaruh pada tiap rentang jarak tidak teratur untuk tiap perubahan rentang jarak.

Pada analisis menggunakan jarak menuju Jalan Panglima Sudirman menunjukkan kelompok rentang nilai $C$ berpengaruh pada tiap rentang jarak yang berbeda.

Tabel 8. Hasil Analisis Peta Tematik Selisih Nilai Individual Terhadap Nilai Massal Pada Properti Rumah Tinggal Dengan Pasar Gresik

\begin{tabular}{ccc}
\hline $\begin{array}{c}\text { Jarak Dari Pasar } \\
\text { Gresik }\end{array}$ & $\begin{array}{c}\text { Kelompok } \\
\text { Nilai }\end{array}$ & Kode \\
\hline$<0,2 \mathrm{~km}$ & A & RU200 \\
& A & RU17 \\
& A & RU96 \\
& A & RU97 \\
& C & RU78 \\
$0,2-0,4 \mathrm{~km}$ & A & RU76 \\
& A & RU77 \\
& A & RU23 \\
& A & RU29 \\
& C & RU117
\end{tabular}

\begin{tabular}{ccc}
$0,4-0,6 \mathrm{~km}$ & A & RU27 \\
$0,6-0,8 \mathrm{~km}$ & E & RU163 \\
& A & RU21 \\
& B & RU100 \\
& B & RU162 \\
$0,8-1 \mathrm{~km}$ & A & RU103 \\
& A & RU199 \\
& A & RU192 \\
& B & RU71 \\
& B & RU201 \\
& B & RU133 \\
\hline
\end{tabular}

Tabel 9. Hasil Analisis Peta Tematik Selisih Nilai Individual Terhadap Nilai Massal Pada Properti Ruko Dengan Jalan Panglima Sudirman

\begin{tabular}{ccc}
\hline $\begin{array}{c}\text { Jarak Dari Jalan } \\
\text { Panglima } \\
\text { Sudirman }\end{array}$ & $\begin{array}{c}\text { Kelompok } \\
\text { Nilai }\end{array}$ & Kode \\
\hline$<0,2 \mathrm{~km}$ & D & RU127 \\
$>0,2-0,4 \mathrm{~km}$ & A & RU191 \\
& D & RU130 \\
$0,4-0,6 \mathrm{~km}$ & A & RU198 \\
& A & RU199 \\
& B & RU2 \\
& C & RU8 \\
\cline { 2 - 3 } $0,6-0,8 \mathrm{~km}$ & C & RU197 \\
& A & RU121 \\
& A & RU122 \\
$0,8-1 \mathrm{~km}$ & A & RU192 \\
& A & RU103 \\
& A & RU132 \\
& B & RU133 \\
\hline
\end{tabular}

Untuk analisis spasial properti rumah tinggal pada jarak menuju pasar gresik di tabel 8 dapat terlihat pada jarak $<0,2 \mathrm{~km}$ bahwa kelompok rentang selisih nilai $A$ menjadi nilai yang berpengaruh. Pada jarak 0,2 - 0,4 km, dapat terlihat bahwa kelompok rentang selisih nilai $A$ menjadi nilai yang berpengaruh. Pada jarak 0,4-0,6 km, dapat dapat terlihat bahwa tidak terdapat kelompok nilai yang berpengaruh. Pada jarak 0,6 - 0,8 km, dapat terlihat bahwa kelompok selisih nilai $B$ menjadi nilai yang berpengaruh. Pada jarak 0,8 - $1 \mathrm{~km}$ menuju Pasar Gresik, kelompok rentang selisih nilai A dan B menjadi nilai yang berpengaruh. Berdasarkan kelompok rentang selisih nilai yang berpengaruh pada tiap rentang jarak, terlihat bahwa tidak terjadi kenaikan kelompok selisih rentang nilai untuk tiap kenaikan rentang jarak.

Pada analisis spasial menggunakan jarak menuju Jalan Panglima Sudirman pada tabel 9 adalah sebagai berikut. Pada jarak $<0,2 \mathrm{~km}$ hanya terdapat 1 sampel yaitu RU127. Pada jarak 0,2 - 0,4 km hanya terdapat 2 sampel yaitu RU191 dan RU130 yang 
memiliki selisih nilai berbeda. Pada jarak 0,4-0,6 $\mathrm{km}$, dapat terlihat bahwa kelompok rentang selisih nilai $\mathrm{A}$ dan $\mathrm{C}$ menjadi kelompok rentang selisih nilai yang berpengaruh. Pada jarak 0,6 - 0,8 km, dapat dapat terlihat bahwa kelompok rentang selisih nilai $A$ menjadi kelompok rentang selisih nilai yang berpengaruh. Pada jarak 0,8 - $1 \mathrm{~km}$ dapat terlihat bahwa kelompok rentang selisih nilai $A$ merupakan kelompok rentang selisih nilai yang berpengaruh.

Adanya titik sampel yang memiliki kelompok rentang selisih nilai berbeda terjadi karena adanya perbedaan karakteristik zona nilai tanah. Karakteristik yang ada dapat berupa faktor lokasi maupun faktor ekonomi.

\section{KESIMPULAN}

Kesimpulan yang diperoleh dari penelitian adalah sebagai berikut:

1. Selisih nilai massal terhadap nilai individual pada properti jenis ruko memiliki nilai selisih tertinggi pada RUK14 dengan selisih sebesar Rp $17.642 .000 / \mathrm{m}^{2}$ terletak pada koordinat $682.808,496 \mathrm{~m}$ dan 9.208.625,588 m. Nilai selisih terendah pada RUK194 dengan selisih sebesar $\mathrm{Rp} 142.541 / \mathrm{m}^{2}$ terletak pada koordinat $682.224 \mathrm{~m}$ dan $9.208 .628 \mathrm{~m}$. Pada properti jenis rumah tinggal, selisih nilai massal terhadap nilai individual memiliki nilai selisih tertinggi pada RU163 dengan selisih sebesar $12.050 .555 / \mathrm{m}^{2}$ yang terletak pada koordinat $682.167,3348 \mathrm{~m}$ dan 9.208.640,582 m. Nilai selisih terendah pada RU122 dengan selisih sebesar $\mathrm{Rp} 75.752 / \mathrm{m}^{2}$ yang terletak pada koordinat $682.975 \mathrm{~m}$ dan $9.206 .983 \mathrm{~m}$.

2. Kenaikan maupun penurunan kelompok rentang selisih nilai yang dominan pada rentang jarak $<0,2 \mathrm{~km} ; 0,2-0,4 \mathrm{~km} ; 0,4-0,6$ $\mathrm{km} ; 0,6-0,8 \mathrm{~km} ; 0,8-1 \mathrm{~km}$ berbeda-beda untuk jarak tiap jenis properti terhadap Pasar Gresik maupun Jalan Panglima Sudirman pada Kecamatan Gresik. Properti ruko mengalami kenaikan dan penurunan kelompok rentang selisih nilai yang dominan untuk tiap rentang jarak dari Pasar Gresik dan kelompok rentang selisih nilai yang cenderung sama yaitu kelompok rentang selisih nilai Rp 6.000.001,00 - Rp 9.000.000,00 untuk tiap rentang jarak dari Jalan Panglima Sudirman. Properti rumah tinggal memiliki kelompok rentang selisih nilai yang cenderung sama yaitu dibawah $\mathrm{Rp}$
3.000.000,00 untuk tiap rentang jarak dari Pasar Gresik dan Jalan Panglima Sudirman.

\section{DAFTAR PUSTAKA}

Ambarita, S., Subiyanto, S., dan Yuwono, B. D., 2016. "Analisis Zona Nilai Tanah Berdasarkan Harga Pasar Untuk Menentukan Nilai Jual Objek Pajak (NJOP) dan Peningkatan Pendapatan Asli Daerah (Studi Kasus : Kec. Semarang Timur, Kota Semarang)". Jurnal Geodesi Undip 5 : 159-167.

Arfah, H., 2017. Dua Tahun Lagi, Gresik Punya Mall dan Hotel Baru, <URL:

http://properti.kompas.com/read/2017/08/04/0829 23721/dua-tahun-lagi-gresik-punya-mal-dan-hotelbaru>. Dikunjungi pada tanggal 19 Februari 2018, jam 19.30.

Kamarzuki, Alie. 2013. Jumlah Penduduk di Kabupaten Gresik, Jawa Timur 1983 - 2013, <URL:https://databoks.katadata.co.id/datapublish/ 2016/05/12/jumlah-penduduk-di-kabupaten-gresikjawa-timur-1983-2013>. Dikunjungi pada tanggal 17 Februari 2018, jam 19.00

Komite Penyusunan Standar Penilaian Indonesia. 2015. Standar Penilaian Indonesia Edisi VI. Jakarta : Komite Penyusunan Standar Penilaian Indonesia.

Oloke, C. O., Simon, R. F., dan Adesulu, F. A., 2013. “An Examination of the Factors Affecting Residential Property

Values in Magodo Neighbourhood, Lagos State". International Journal of Economy, Management and Social Sciences 2 : 639-643.

Prawoto, A. 2015. Teori \& Praktek Penilaian Properti Edisi Ketiga. Yogyakarta : BPFE.

Richardson, H. W. 1984. Urban Economics. Hinsdale : The Dryden Press.

Republik Indonesia. 2009. Undang-Undang No. 22 Tahun 2009 Tentang Lalu Lintas dan Angkatan Jalan. Lembaran Negara RI Tahun 2009, No. 96. Sekretariat Negara. Jakarta.

Republik Indonesia. 2010. Peraturan Menteri Keuangan No. 150/PMK.03/2010 tentang Klasifikasi dan Penetapan Nilai Jual Objek Pajak Sebagai Dasar Pengenaan Pajak Bumi dan Bangunan. Sekretariat Kabinet RI. Jakarta 